\title{
PERSEPSI MASYARAKAT TERHADAP ADAT WALIGORO (Studi Pada Desa Petisbenem Kecamatan Duduksampeyan Kabupaten Gresik)
}

\author{
Zahrotul Wardah, M. Mansur, M. Syahri \\ FKIP Universitas Muhammadiyah Malang, Indonesia \\ Email:wardah488@gmail.com
}

\begin{abstract}
ABSTRAK
Adat waligoro merupakan budaya yang dimiliki masyarakat Desa Petisbenem sebagai pelengkap pelaksanaan pernikahan. Tujuan penelitian: 1) persepsi masyarakat terhadap adat pernikahan waligoro di Desa Petisbenem, 2) pelaksanaan adat pernikahan waligoro, 3) keseuaian pelaksanaan adat pernikahan waligoro dengan perkembangan zaman. Metode penelitian menggunakan penelitian kualitatif deskriptif dengan sumber data adalah pemerintah Desa Petisbenem, masyarakat dan tokoh adat. Hasil penelitian: 1) sebagian besar masyarakat menganggap waligoro sebagai budaya yang harus dilakukan terus menerus karena mereka percaya adanya dampak yang akan menimpa kehidupan calon pengantin, 2) adat pernikahan waligoro dilaksanakan bersamaan acara walimah pada malam hari sebelum akad nikah dengan menyajikan dua sesajen yang diibaratkan calon pengantin, 3) seiring berkembangnya zaman, adat pernikahan waligoro tetap dilaksanakan dan sudah menjadi tradisi bagi masyarakat.
\end{abstract}

Kata Kunci: Adat waligoro; Masyarakat; Pernikahan adat; Persepsi

\begin{abstract}
Waligoro custom is a culture that belongs to the people of the village of Petisbenem as a complement to the implementation of marriage. Research Purpose: 1) community perceptions of the Waligoro wedding customs in Petisbenem Village, 2) the implementation of the Waligoro wedding customs, 3) the conformity of the implementation of the Waligoro wedding customs with the times. The research method using descriptive qualitative research with data sources is the Petisbenem Village government, community and traditional leaders. The results of the study: 1) most people consider waligoro as a culture that must be carried out continuously because they believe that there will be an impact on the life of the bride and groom, 2) the custom of waligoro weddings is held simultaneously at the evening before the marriage ceremony by presenting two likened offerings bride and groom, 3) along with the development of the times, the custom of waligoro marriage is still carried out and has become a traditional for the community.
\end{abstract}

Keywords: Custom waligoro; Society; Customary marriage; Perception

\section{PENDAHULUAN}

Indonesia memiliki berbagai macam suku dan kebudayaan yang khas pada masing-masing daerah, salah satu unsur budaya yang masuk sekaligus berpengaruh dalam kehidupan masyarakat adalah sistem perkawinan sebagai bagian dari kemasyarakatan yang hidup pada perilaku masyarakat. Prosesi pernikahan di Indonesia biasanya sesuai dengan adat yang dianut dengan berbagai macam ritual adat dan sarat dengan simbol-simbol kehidupan. Masyarakat tradisional yang belum mengenal agama modern dan belum terpengaruh oleh intervensi negara, perkawinannya dilakukan secara adat. Perkawinan cukup disyahkan oleh ketua adat dan disaksikan oleh kerabat (lakilaki maupun perempuan). Perkawinan diartikan sebagai salah satu dimensi kehidupan yang penting bagi manusia, begitu pentingnya perkawinan maka tidak heran jika agama-agama di dunia mengatur masalah perkawinan bahkan tradisi atau adat masyarakat dan Institusi Negara juga mengatur perkawinan yang berlaku 
di kalangan masyarakatnya (Santoso, 2016:413).

Masyarakat adalah kesatuan hidup manusia yang berinteraksi menurut suatu sistem adat istiadat tertentu yang bersifat kontinyu dan terikat oleh suatu rasa identitas bersama. Kontinuitas merupakan kesatuan masyarakat yang empat ciri yaitu

: 1) Interaksi antar warga-warganya; 2) Adat istiadat; 3) Kontinuitas waktu; 4) Rasa identitas yang kuat dan mengikat semua warga (Koentjaningrat, 2009:115).

Prosesi pernikahan yang di laksanakan di Indonesia sangat beragam seperti pada wilayah Jawa Timur tepatnya di Kabupaten Gresik memiliki keberagaman dalam melaksanakan prosesi pernikahan, salah satunya kemanten jadur yang biasa di lakukan oleh masyarakat Desa Lumpur Kabupaten Gresik prosesi ini terdiri dari sungkem, arak-arakan, dan temu manten dengan di iringi alat musik berupa terbang dan jidor (Qudus,2013:134). Selain itu pada Kecamatan Duduksampeyan tepatnya di Desa Petisbenem ada sebuah prosesi serupa dalam serangkaian prosesi walimah yang di sebut waligoro, waligoro ini dilaksanakan pada malam hari sebelum akad nikah biasanya calon pengantin dari desa tersebut disyaratkan untuk menyediakan sesajen waligoro dalam pernikahannya, karena hal ini sudah menjadi tradisi atau ciri khas dari daerah tersebut ketika akan melangsungkan sebuah pernikahan. Sesajen yang di sajikan dalam waligoro ini ada dua macam yaitu untuk calon pengantin laki-laki dan pengantin perempuan.

Masyarakat Desa Petisbenem mayoritas beragama islam, namun sebagian besar masih banyak yang mempercayai tradisi waligoro dalam pelaksanaan pernikahan, kepercayaan terhadap waligoro ini di dukung dengan adanya kejadian-kejadian buruk atau musibah yang menimpa para pasangan pengantin pada waktu pernikahan maupun setelah pernikahan berlangsung jika tidak melaksanakan waligoro sehingga sebagian besar masyarakat Petisbenem mengaitkan dan membuat sebuah kesimpulan bahwa kejadian tersebut akibat melanggar persyaratan pernikahan yang sudah di percayai secara turun menurun.

\section{METODE}

Penelitian ini menggunakan pendekatan kualitatif karena tujuan yang ingin dicapai dalam penelitian ini adalah mengetahui bagaimana persepsi masyarakat terhadap adat waligoro pada pernikahan dan apakah pelaksanaan pernikahan adat waligoro di Desa Petisbenem masih sesuai seiring berkembangnya zaman. Pendekatan yang digunakan berupa pendekatan deskriptif, menurut Zuriah (2009:47) menyatakan bahwa penelitian deskriptif adalah penelitian yang di arahkan untuk memberikan gejalagejala, fakta-fakta atau kejadian secara sistematis dan akurat mengenai sifat-sifat populasi atau daerah tertentu. Penelitian ini dilakukan di Desa Petisbenem Kecamatan Duduksampeyan Kabupaten Gresik karena sumber data yang digunakan adalah Masyarakat dan Tokoh adat Desa Petisbenem.Menurut Sugiyono (2008:225) teknik pengumpulan data dapat dilakukan pada natural setting (kondisi yang alamiah) yaitu dengan tiga macam teknik: 1) Observasi, 2) Dokumentasi, 3) wawancara. Berdasarkan hasil wawancara menggunakan teknik tersebut peneliti kemudian menyusun data yang diperoleh, melakukan sintesa dan membuat kesimpulan. Menurut Sugiyono (2008:246) analisis data kualitatif dilakukan secara interaktif dan berlangsung secara terus menerus sampai selesai, hingga data jenuh. Aktivitas dalam analisis data yaitu reduksi data, penyajian data dan penarikan kesimpulan.

\section{HASIL DAN PEMBAHASAN}

Berdasarkan hasil penelitian dan data yang telah diuraikan di atas akan dijelaskan lebih lanjut mengenai pembahasan yang mengacu pada rumusan masalah. Adapun 
pembahasannya adalah sebagai berikut :

Persepsi Masyarakat Terhadap Adat Pernikahan Waligoro di Desa Petisbenem Kecamatan Duduksampeyan Kabupaten Gresik.

Perkawinan merupakan suatu hubungan yang terjalin antara laki-laki dan perempuan untuk membina rumah tangga. Pernikahan tidak hanya mempersatukan kedua pasangan pengantin tetapi juga mempersatukan kedua keluarga.Adat dan kebiasaan dalam melaksanakan pernikahan yang dianut oleh masyarakat Indonesia berbeda-beda. Perkawinan menurut hukum adat tidak hanya sebuah ikatan antara seorang pria dengan wanita sebagai suamiistri saja tetapi suatu hubungan hukum yang menyangkut para anggota kerabat dari pihak suami maupun istri. Sehingga dengan adanya perkawinan dapat dijadikan sebagai penerus silsilah orang tua dan kerabat menurut garis keturunan ayah maupun ibu. Beberapa sistem kekerabatan yang dianut masyarakat Indonesia antara lainpatrilineal, matrilineal dan sistem kekerabatan parental (Hadikusuma, 2003:70).

Perkawinan dalam arti perikatan adat ialah perkawinan yang mempunyai akibat hukum terhadap hukum adat yang berlaku di masyarakat.Akibat hukum ini sudah ada sebelum perkawinan hingga setelah perkawinan. Setelah terjadinya ikatan perkawinan maka timbul hak dan kewajiban orang tua (termasuk keluarga/kerabat) menurut hukum adat setempat, sejauh mana ikatan perkawinan itu membawa akibat hukum dalam perikatan adat seperti kedudukan suami dan kedudukan istri hingga harta yang timbul akibat terjadinya perkawinan tergantung pada sistem kekerabatan, bentuk dan sistem perkawinan adat setempat (Astuti,2010:104).

Menurut Aristoni dan Abdullah (2016:83) pernikahan dapat dijadikan sebagai dasar untuk membentuk keluarga (rumah tangga) yang bahagia dan kekal bagi bangsa Indonesia, sehingga dapat dimaknai bahwa suatu perkawinan yang dikehendaki perundangan nasional bukan saja merupakan perikatan keperdataan melainkan sebagai perikatan keagamaan dan perikatan kekeluargaan.

Pada pembahasan ini peneliti melihat ada sebuah fenomena yang terjadi di Desa Petisbenem dengan budaya yang unik yaitu ketika akan melangsungkan pernikahan biasanya masyarakat mengadakan acara walimah pada malam hari dengan mengundang beberapa kerabat dan tetangga untuk mendoakan calon pengantin agar diberikan kebahagiaan dan keharmonisan dalam membina rumah tangga. Pada prosesi walimah tersebut terdapat adat yang masih dilaksanakan oleh masyarakat Desa Petisbenem dari zaman dahulu sampai sekarang masih tetap dipertahankan dan diwariskan kepada generasi muda yaitu waligoro.

Berdasarkan hasil wawancara yang telah peneliti lakukan dapat diketahui bahwa masyarakat ingin menjadikan adat waligoro sebagai identitas sehingga mereka masih menjaga warisan budaya agar tetap dijalankan secara berkelanjutan

Persepsi yang dikemukakan masyarakat sebagian besar mengarah pada pandangan yang bersifat mitologi. Mitos-mitos yang dibangun oleh masyarakat terdahulunya sehingga hal tersebut menjadi kepercayaan yang sudah turun temurun diyakini sampai sekarang. Adat waligoro sudah berkembang pada masyarakat sehingga sajian waligoro ini sudah pasti ada pada serangkaian acara pernikahan di Desa Petisbenem. Adanya kejadian yang terjadi secara kebetulan dianggap menjadi akibat bagi orang-orang yang tidak mau menyajikan waligoro, maka mayoritas masyarakat menyatakan bahwa dirinya enggan meninggalkan adat waligoro ini karena takut akan dampak yang terjadi di masa akan datang. Masyarakat menganggap bahwa sesaji waligoro sebagai sebuah sedekah hasil bumi kepada kerabat dan tetangga sebagai 
wujud rasa syukur terhadap Tuhan Yang Maha Esa agar pelaksanaan pernikahan diberi kelancaran dan keselamatan.

\section{Pelaksanaan Adat Waligoro Pada Pernikahan di Desa Petisbenem Kecamatan Duduksampeyan Kabupaten Gresik}

Pelaksanaan pernikahan dengan adat waligoro merupakan bagian dari budaya masyarakat yang sudah menjadi kebiasaan sehingga tetap konsisten dilakukan oleh masyarakat hingga saat ini. Budaya tersebut tidak bisa dihilangkan oleh aturan hukum tertulis karena merupakan norma adat istiadat yang ada di masyarakat setempat yang mempunyai tujuan untuk mempertahankan nilai, kebiasaan, dan norma dari nenek moyang terdahulu karena kepercayaan mereka terhadap adat waligoro sangat kuat. Pendapat tentang adanya kepercayaan adat waligoro merupakan hasil dari pemikiran sehingga menjadi kebenaran, mitos rasional dan kebenaran ilmiah. Menurut Khaziq (2009:31) mitos merupakan pemikiran sederhana ketika seseorang tidak bisa berfikir rasional dan tidak bisa menjawab dengan akalnya.

Pelaksanaan adat waligoro pada pernikahan di Petisbenem merupakan sebuah sikap atau upaya memberikan definisi untuk mempertahankan tradisi yang sudah dilakukan oleh para leluhur, pada kehidupan masyarakat banyak sekali aturan yang berasal dari nenek moyang aturan tersebut menjadi pedoman untuk bertindak dan memberi setiap individu sebuah identitas. Hidup bermasyarakat membuat manusia dituntut untuk lebih mengedepankan kepentingan kelompok daripada kepentingan diri sendiri, sebagaimana hubungan individu dalam masyarakat yang pada hakekatnya merupakan fungsional, sekaligus sebagai kolektif yang terbuka dan saling ketergantungan antara satu dengan yang lain. Hasil wawancara juga menunjukkan bahwa faktor yang melatar belakangi adanya adat waligoro karena muncul hal-hal buruk yang akan terjadi pada calon pasangan pengantin di kehidupan rumah tangga nya kedepan, sehingga masyarakat masih memegang teguh budaya yang mereka miliki.

Prosesi adat waligoro pada pernikahan di Desa Petisbenem merupakan kebiasaan yang tumbuh dan dianggap memiliki ikatan dan pengaruh yang kuat dalam masyarakat. Pada pernikahan di Petisbenem adat waligoro dilaksanakan bersamaan dengan serangkaian acara walimah biasanya tuan rumah menata kedua sesaji waligoro di atas meja yang di letakkan di sudut ruang tamu dengan di hiasi 2 lampu ublik. Hal tersebut agar waligoro menjadi pusat perhatian masyarakat yang datang pada acara walimah layaknya kedua mempelai kemudian setelah acara walimah selesai kedua sesaji tersebut di bagikan oleh tokoh adat disana atau bisa juga pemimpin do'a pada acara walimah kepada masyarakat yang hadir, cara pembagian waligoro ini cukup menarik karena bagian ayam baik yang jantan maupun betina hanya boleh dibagikan dan di makan oleh laki-laki yang masih perjaka saja selebihnya dibagikan merata kepada masyarakat lainnya yang sudah memiliki keluarga. Walimah dilaksanakan pada malam hari sebelum dilangsungkan akad nikah.Begitu sakralnya makna yang terkandung dalam adat waligoro sehingga ayam yang digunakan harus benar-benar ayam yang belum pernah bertelur, menurut penjelasan salah satu masyarakat waligoro diibaratkan sebagai kedua calon mempelai pengantin yang masih perjaka dan perawan sehingga ayam yang di panggang untuk sesaji waligoro ini adalah ayam yang belum pernah bertelur.

Temuan peneliti mendefinisakan, tradisi waligoro menjadi bagian penting dalam prosesi walimahnikah karena didalamnya terdapat simbol-simbol yang mempunyai makna tersendiri pada satuan 
sesaji yang dihidangkan. Pernikahan yang dilaksanakan masyarakat Desa Petisbenem secara umum sama seperti pernikahan pada umumnya, setelah perkawinan sah menurut hukum masing-masing agama dan kepercayaannya maka perkawinan harus dicatatkan di Catatan Sipil bagi suami istri yang bukan beragama islam, sedangkan bagi yang beragama islam perkawinannya dilangsungkan oleh Kantor Urusan Agama (Sari, 2006:98).

\section{Kesesuaian Pelaksanaan Adat Waligoro Pada Pernikahan di Desa Petisbenem Dengan Perkembangan Zaman}

Perkawinan merupakan sebuah perintah agama yang diatur oleh syariat islam dan merupakan dan merupakan satu-satunya jalan penyaluran seks yang disahkan oleh agama islam. Perkawinan sesungguhnya bukan hanya sekedar sebagai sarana penyaluran kebutuhan seks, akan tetapi pernikahan juga menjanjikan perdamaian hidup bagi manusia (Atabik dan Muhdiiah, 2014:287).

Waligoro merupakan sesaji yang disajikan dalam tempeh, ada dua sesaji waligoro yang diibaratkan sebagai calon pengantin laki-laki dan calon pengantin perempuan. Sesaji dalam tempeh yang diibaratkan calon pengantin laki-laki berisi ayam panggang (jantan), nasi tumpeng, urap-urap, bunga, telur, air badhek, tujuh buah ketupat, lima buah lepet dan bumbu masak dapur seperti kunir, jahe, lengkuas dll. Sedangkan dalam tempeh yang diibaratkan sebagai calon pengantin perempuan berisi ayam panggang (jantan), nasi tumpeng, urap-urap, bunga, telur, air badhek, delapan buah ketupat, lima buah lepet dan bumbu masak dapur seperti kunir, jahe, lengkuas dan di tambah dengan bedak, sisir dan cermin. Sajian adat waligoro yang terus dilakukan secara turun temurun temyata memiliki makna yang diibaratkan seperti kehidupan manusia dalam menjalani rumah tangga.
Berdasarkan hasil penelitian yang telah peneliti lakukan di Desa Petisbenem mengenai kesesuaian pelaksanaan adat waligoro pada pernikahan dengan perkembangan zaman, pada umumnya masyarakat masih melakukan adat waligoro karena mengikuti tradisi yang sudah turun temurun sejak dahulu. Masyarakat juga mengatakan bahwa mereka melaksanakan adat waligoro sebagai bentuk melestarikan warisan budaya leluhur yang berakar dari budaya lokal dan masyarakat yang memegang peranan penting dalam kehidupan, sehingga masyarakat merasa adat waligoro bisa selalu ada pada pernikahan di Desa Petisbenem karena selagi tidak melanggar norma dan kepercayaan dirinya tidak akan meninggalkan waligoro karena sudah ada sejak dahulu.

Hingga saat ini orang yang membuat sesaji waligoro masih orang-orang tertentu saja yang merupakan keturunan asli dari buyut Desa Petisbenem terdahulu. Saat ini hanya ada satu orang saja yang bisa membuat waligoro di setiap Dusun yakni di Dusun Petis dan Dusun Benem, karena bukan sembarang orang yang bisa membuat sajian waligoro. Seluruh sajian waligoro hingga setiap detail ukuran bahanbahan yang digunakan harus tepat dan ada do'a maupun ritual khusus yang dilakukan oleh orang yang memasak sajian waligoro.

Adanya adat waligoro pada pernikahan menjadi sebuah produk sosial dari nenek moyang yang diwariskan kepada generasi penerusnya dan menjadi suatu kebiasaan dalam fenomena sosial. Pada saat ini masyarakat mengenal waligoro sebagai sebuah sesaji yang digunakan dan harus ada pada acara walimah pernikahan sebagai sebuah mitos dan sebagainya, namun budaya waligoro sangat kuat sehingga beberapa orang mengembangkan dan memodifikasi hal ini sebagai sebuah ciri khas Desa Petisbenem dan menjadi pembeda dengan pernikahan di Desa lainnya.

Berdasarkan perkembangan zaman yang sudah modern seperti saat ini menggunakan 
sesaji waligoro pada pernikahan dipahami sebagian masyarakat sebagai istilah tasyakuran atau wujud rasa syukur kepada Allah SWT karena dianggap budaya yang sudah turun temurun dan masyarakat menerima tanpa mempertanyakan secara rumit. Masyarakat diharapkan dapat menjaga warisan budaya guna melestarikan adat istiadat yang ada di Desa Petisbenem karena waligoro merupakan warisan yang dapat di pertahankan dan diturunkan kepada anak cucu yang akan datang.

\section{SIMPULAN}

Berdasarkan hasil penelitian mengenai persepsi masyarakat terhadap adat waligoro, maka dapat ditarik kesimpulan bahwa sebagian masyarakat Desa Petisbenem melaksanakan adat waligoro tanpa mengetahui makna yang terkandung dalam waligoro namun hal tersebut dianggap sebagai wujud rasa syukur kepada Tuhan Yang Maha Esa atas limpahan rezeki yang diberikan kepada mereka. Adat waligoro dilaksanakan bersamaan dengan acara walimah pada malam hari sebelum akad nikah. Seiring berkembangnya zaman adat waligoro dianggap sebagai pelengkap dalam prosesi pernikahan karena secara umum masyarakat saat ini juga tidak mengetahui makna sebenarnya yang ada dalam sajian waligoro. Berdasarkan uraian tersebut masyarakat diharapkan tetap melaksanakan pernikahan sesuai ketentuan UndangUndang tentang perkawinan meskipun mereka menggunakan adat waligoro namun secara administratif harus sesuai dengan peraturan sipil.

\section{DAFTAR PUSTAKA}

Abdullah, Junaidi \& Aristoni. 2016. 4 Dekade Hukum Perkawinan di Indonesia: Menelisik Problematika Hukum dalam Perkawinan di Era Modernisasi. Jurnal Yudisia , 7 (1): 83.
Astuti, Linda P. 2010. Upacara Adat Perkawinan Priyayi Desa Ngembal Kecamatan Tutur Kabupaten Pasuruan. Skripsi. Malang: Fakultas Ilmu Sosial Universitas Negeri Malang.

Atabik, Ahmad \& Khoridatul Mudhiiah. 2014. Pernikahan dan Hikmahnya Perspektif Hukum Islam. Jurnal Yudisia, 5 (2) : 287.

Hadikusuma, Hilman. 2003. Hukum Perkawinan Adat dengan Adat Istiadat dan Upacara Adatnya (Cetakan VI). Bandung: Citra Aditya Bakti.

Khaziq. 2009. Islam dan Budaya Lokal Belajar Memahami Realitas Agama Dalam Masyarakat. Yogyakarta: Teras. Koentjaningrat. 2009. Pengantar Ilmu Antropologi (Cetakan 2). Jakarta: Rineka Cipta.

Qudus, A.Z.A. 2013. Kemanten Jadur (Studi Etnografi Tentang Makna Simbolik dalam Prosesi Perkawinan di Kelurahan Lumpur, Kecamatan Gresik Kabupaten Gresik) dalam Antro Unair Dot Net; 2 (1) : 134-135.

Santoso. 2016. Hakekat Perkawinan Menurut Undang-Undang Perkawinan; Hukum Islam dan Hukum Adat. Jurnal Pemikiran Hukum dan Islam; 7(2) : 413, 417-418.

Sari, V.E.P. 2006. Asas Monogami Dalam Hukum Perkawinan di Indonesia. Jurnal FH, 6 (1) : 98.

Sugiyono. 2008. Metode Penelitian Pendidikan Pendekatan Kuantitatif; Kualitatif; dan R\&D (cetakan 4). Bandung: Alfabeta.

Zuriah, N. 2009. Metodologi penelitian Sosial dan Pendidikan. Jakarta: PT. Bumi Aksara. 